\title{
Police Leadership Development: Intentions and Critical Success-Factors
}

\author{
Jan Ole Vanebo \\ Nord Troendelag University College of (HiNT), Norway \\ jan.o.vanebo@hint.no \\ Brita Bjørkelo \\ Norwegian Police University College, Oslo, Norway \\ bribjo@phs.no \\ Terje Aaserud \\ Norwegian Police University College, Oslo, Norway \\ terase@phs.no
}

\section{ABSTRACT}

The Norwegian Police Service (NPS) have been heavily criticized after the 22 July 2011 terror attacks at Utøya and in Oslo. One of the evaluation reports stated three shortcomings in the NPS: culture, attitudes and leadership. Management and leadership in the NPS needs to be improved and strengthened, and this shall take place among other things, with the help of a policy document on Civil Service Leadership, elaborated into a manifest called Plattform for medarbeiderskap (Platform of Employeeship for the NPS). The policy document pertains to how the public sector in general ought to be managed, and the document is based on leadership research and is in accordance with mainstream management theory. The idea of formulating a principle of management that would characterize the classical contributions is also evident in this document. This paper addresses two problems: How can value-based police leadership skills be operationalized and measured, and what are the key critical factors in transferring value-based police leadership principles into improved leadership practices?

Keywords: leadership, police, development, competence, value-based, pipeline, Norway, Sweden, Denmark

$J E L: M 14$

\section{Introduction}

Successful implementation and integration of a value-based leadership policy is, according to several researchers (Barlett \& Ghoshal, 1995; Busch \& Murdock, 2014; Selznick, 1957) dependent on ethical, transformational 
and authentic leadership. In addition to this, successful implementation and integration depends on the three leadership processes, (1) anchored on the values that are present in the organization, (2) based on ethical standards and (3) aimed at creating functional values. According to Selznick (1957), this implies that transformational leadership processes must be anchored on the present professional and organizational cultures and not be in conflict with the organization's basic values. Further, leaders (change agents) must be able to handle the instrumental and the social-constructive (sense making) elements of creative leadership in order to build a bridge from a general leadership policy into the social structure of an organization, which in this case is the police. Leaders should aim at receiving support of the leadership policy at all levels of the organization, as well as promote and protect it.

\section{Leadership Context}

Police are required to understand and effectively operate in a complex social, political and organizational environment (Pearson-Goff \& Herrington, 2014). After having done a review of the police leadership literature, the authors described the situation in the following manner: "Although competencybased development approaches have much to offer in that they provide clear guidance for when one has achieved such leadership skills, the question remains whether we are using these frameworks to develop leaders, because there is a shared understanding about what characterizes effective leadership, or because of a received wisdom based on flawed evidence focusing on perceptions. The findings from this review suggest the latter" (Pearson-Goff \& Herrington, 2014, p. 21).

The review included research from mainly the "majority world" (USA, UK, Canada, New Zealand and Australia), and aimed at investigating (1) what was known about the characteristics of police leaders and (2) the activities the leaders engage in. The findings showed that police leader characteristics were such as ethical, trustworthy, legitimate, being role models and communicative, involved in decision making and thinking ability (Pearson-Goff \& Herrington, 2014). Activities of police leaders were characterised by such as the ability to create a shared vision, develop organizational commitment, care for employees, to drive and manage change as well as problem solving. Although the systematic review included synthesized findings from 57 peer review publications, the authors concluded that despite the work done on the topics to date we still have little understanding of "what works" in police leadership. The authors call for research into objective measures of effective leadership behaviours and their relationship to "organizational outcomes, to consider the heterogenic nature of police leadership, and to help inform our understanding of the best ways that individuals can be prepared for the leadership tasks" they are facing (Pearson-Goff \& Herrington, 2014, p. 21-22). This paper will investigate how value-based police leadership skills may be operationalized and measured and what critical factors may be in transferring 
these into improved leadership practices. Based on the current emphasis in the NPS on The Platform of Employeeship or co-workership, we will now look into which types of leadership this may indicate and what critical factors for successful implementation and integration may be.

Co-workership (also known as employeeship or employee engagement) is described as something more than to develop a cooperative relationship with one's leader, but also about the relationship to one's work tasks, colleagues, clients, students, and co-citizens (Tengblad, 2009; Tengblad \& Andersson, 2014; Velten, 2008) and can be described as a form of self-leadership or a principle of leadership where responsibility and scope of action is decentralized in so that leaders may delegate parts of their work tasks to their employees. The common platform in the NPS is founded on two principles: the platform is exposing values, attitudes and normative behaviour and a common platform for all persons employed in the police - both superiors and subordinates. The philosophy behind the platform is that both managers (formal leaders) and employees are employees. The platform contains 4 basic values exposed in an imperative form: I am brave, I have a holistic perspective, I show respect and I am focused. The formal leaders (managers) have some additional requirements: set direction and precipitate and enable change, motivate and develop the employees and achieve results in cooperation in an interaction with others. The intention behind the platform is that it should be a leverage to influence and change attitude, culture and leadership in the police. The following four success-factors are listed in the platform manifest, that the (1) aim, intention and level of ambition should be distinct, (2) that the platform must be regarded as relevant, that (3) adequate commitment to the platform from top officers in the police must be present and that (4) the plan for implementation and following up is distinct.

\section{Value-Based Leadership in a Front-Line Organization}

Value-based leadership can be traced back to Selznick (1957) and House (1996). Selznick's institutional approach is that both ends and means have strong value anchoring, especially in public organizations. He claims that key tasks in institutional (creative) leadership are: the definition of institutional mission and role; institutional embodiment of purpose; the defence of institutional integrity and the ordering of internal conflict. Drawing on House (1996), Busch and Murdock (2014) states that a leader with a value-based perspective is able to express a vision while appealing to employee's central values and unconscious motives, so that they become motivated to engage in the organization's overall vision. These conditions have led to value-based leadership being largely associated with transformational leadership (Bass, 1991).

The policy document on Civil Service Leadership in Norway clearly specifies the premise for managers within the state and focus on four leadership functions: 
(1) Strategic and operational functions, (2) building relations, (3) information and (4) communication. Strategic functions describe that managers at all levels have to make choices and set priorities, for example with regard to performance; competencies and learning; involvement and cooperation and coordination. Before such decisions are taken, the expectations of higher authorities, target groups and citizens as well as the manager's own staff must be clarified. All Civil Service managers are responsible for following up sectorial policy objectives in their own areas and for complying with the general regulations and values governing the public administration. Managers must (1) decide how financial, human and other resources are to be used in order to ensure the best possible performance, and organise personnel management accordingly, (2) choose methods, coordination procedures and forms of leadership that produce the best results, (3) and view facts in the light of expert assessments of risks and impacts. Further, (4) decision making can be particularly demanding for Civil Service managers since their decisions often affect the general public.

Operational functions describe how managers often have to introduce, develop and maintain systems in order to ensure that tasks are performed and goods and services are delivered. This applies in particular to technical, financial and personnel systems. The manager must ensure best possible general administration, personnel management, financial management and quality assurance. In large agencies, the responsibility for various operational functions may be delegated to managers at lower levels. In small agencies, the top senior executive may have to take care of a number of tasks relating to day-to-day operations. High-level officials must in any case distribute the responsibility for operations and results, and ensure that the agency complies with the relevant requirements and standards, for example for financial management, quality, and health, safety and environment.

Building relations describes how managers must establish, foster and develop relations both within and outside their own agencies. All Civil Service managers are part of a politically governed apparatus, including those who have little or no direct contact with the governing political leadership in their day-today work. Building relations is important for ensuring that political signals are picked up and implemented effectively. Managers must build solid working relations with their own staff and the employees' organizations. High-level officials have a particular responsibility for ensuring that sound personnel management is practiced throughout the agency.

Communication and information functions describe how the Civil Service shall be characterized by transparency both in relation to the general public and the employees and between the various parts of the public administration. This means that managers have to ensure adequate communication and the dissemination of necessary information. Information and communication have their own intrinsic value, but are also vital for successful task solution and for developing democracy in working life and society as a whole. 
The policy document pertains to how the public sector in general ought to be managed, and the document is based on leadership research and is in accordance with mainstream management theory. The idea of formulating a principle of management that would characterize the classical contributions is also evident in this document (Vanebo \& Andersen, 2014).

The police in general and the NPS especially have a vital role in the civil society. For one, it is one of few civil institutions, along with health care, that is allowed the use of legitimized force against its own population, when urgent (see e.g., van Ewijk, 2012). This powerful role necessitates knowledge based leadership and management (Coleman, 2008; Gundhus, 2013). One initiative in this regard is Pearls in Policing, which is an initiative for top-level police leaders from all over the world. The aim is to make use of professional knowledge and experience to find solutions for international safety and security issues. The aim of this initiative is to stimulate future-oriented, out-of-the-box thinking by the use of informal, think-tank settings, away from the everyday hustle and bustle and the glare of the media. In this way, international police leaders are encouraged to brainstorm more intensely and creatively. In a paper presented at the 2012 Pearls-conference in Singapore, contributions were made from police forces in Denmark, Cayman Islands, Germany, Belgium, South-Australia and the Netherlands. According to these discussions, a frontline organisation has the following characteristics (see e.g., Smith, 1965): (1) the initiative lies at the base of the organisation, not at the top, (2) there is a large degree of independence in the performance of tasks, (3) there are great obstacles to hierarchical management and for the police, there are two specific additional characteristics (Tops, Bruijn, Spelier, Hogeboom, \& Arkel, 2012), (4) frontline activities are complex, subject to conflict and ethically loaded and (5) the higher aim is more important than individual lives. It seems reasonable to assume that developing the learning capacity of a frontline organisation with the characteristics described above also involves special requirements.

Curiously, little has been found out about this up to now. A great deal has been written about police education, but this is based particularly on the question of how people learn best at different levels of education (secondary vocational education, higher vocational education, etc.). Relatively little attention has been devoted to the institutional or organisational aspects. What are the institutional conditions for turning the police into a learning organisation? Under what conditions do police officers want to learn? According to Tops et al. (2012) the following factors emerge: (1) the basis must be in order, (2) the bosses must provide credible support, and (3) "the big picture" must be clear. From this description of a way to work knowledge based in the police we turn to one way of working in practice, through employeeship. 


\section{Critical Success-Factors: Enabling Creative Leadership}

In general, the analysis of critical success-factors must focus on the concept or architecture of the new leadership policy, the intentions behind the policy decision, the implementation decision and the integration of the new leadership policy into the (hopefully: improved) leadership practice. Employeeship means to a large extent self-leadership and three forms of self-leadership can be identified (Kristensen \& Pedersen , 2013): general selfleadership, self-existence leadership and strategic self-leadership. The first two have to do with autonomy for the workers and commitment to oneself, and the third one (strategic self-leadership) is about aligning self-leadership to mission, role and the strategic logic of the organization. Strategic logic is defined as (Sanchez \& Heene, 2004, p. 5) "an organization's operative rationale for achieving its goal through coordinated deployments of resources", shared ideas of the people in the organization about the nature of the organization's goals for creating value, the resources needed to achieve those goals, the ways resources will be coordinated in pursuing those goals, and how value created by the organization will be distributed to all the stakeholders that provide resources to the organization.

Employees should understand the work on three levels to be able to lead themselves (Kristensen \& Pedersen, 2013, p. 52): (1) understanding the business (mission and role): Why do I work?; (2) understanding the objective: What is the objective of the work? and (3) understanding the task: How shall I work?

An obvious statement will be that that adequate managerial skills are a precondition for successful implementation and integration of the Platform of employeeship.

Looking at the components of employeeship, this may seem as somewhat related to the elements of transformational leadership. Transformational leadership can be described as a leader's ability to create commitment to common goals, motivate, and inspire (Bass, 1991; Hetland \& Sandal, 2003). A related concept is transformational change, which is described as strategic change which "affects a number of the major systems in the organization". This is a "multilayered process affecting different levels of the organization and even the context of the organization's operation, simultaneously" (Ferlie et al., 1996, p. 89). Ferlie and colleagues suggest that there are six indicators for transformational change, namely (1) the existence of multiple and interrelated changes across the system as a whole, (2) the creation of new organizational forms at a collective level, (3) the development of multilayered changes which impact below the whole system, at a unit and individual level, (4) the creation of changes in the services provided and the mode of delivery, (5), the reconfiguration of power relations (especially the formation of new leadership groups), and the (6) development of a new culture, ideology, and organizational meaning (p. 94). 
Another associated concept is distributed leadership, which is described by co-leadership and leading with others as opposed to hierarchical leadership through others (Gronn, 2002). Authentic leadership describes similar leadership qualities in the form of trustworthy support from one's superior (Avolio \& Gardner, 2005), with key characteristics such as the leader being him- or herself, as opposed to playing a role, being governed by one's own convictions as opposed to driven by a need for status, honor and personal benefits, basing one's actions on personal values and convictions.

Even though many have described transformational leadership as one of the types performed in the police, others have pointed at the difficulty of finding this in empirical research (Cockcroft, 2014). This has led some to argue that the simplistic way of dichotomising transactional and transformational leadership in the police "fails to recognize the nuances of organizational life", and that synthesising the two leadership models may "be a way of overcoming" these criticisms (Cockcroft, 2014, p. 12). In a Norwegian study of leaderships styles in the NPS (Fjærli, 2008), the author also struggled to find this dichotomy empirically and as a result suggested the term "transleadership" (our translation). Even though laissez-faire leadership, the lack of leadership, turned out to be the form of leadership that mostly characterised leadership style in the study of one Norwegian police district and a total of 140 respondents. Thus, while transformational leadership may be the theoretical leadership framework that to greatest extent resembles employeeship, the empirical evidence suggest that the most common leadership styles are laissez-faire and trans-leadership. Based on this policy outline, we will in the following look into some of the studies on what may be described as leadership competencies in the police.

\section{Leadership Competence}

Leadership skills are "the ability to use one's knowledge and competencies to accomplish a set of goals or objectives" (Northouse, 2013). According to Katz (1955), leadership requires three forms of competencies or skills (1) technical skills, which are "an understanding of, and proficiency in a specific kind of activity, particularly one involving methods, processes, procedures, or techniques", and involves "specialized knowledge, analytical ability within that speciality, and facility in the use of the tools and techniques of the specific discipline" (p. 91). Human skills (2) are characterized by the "ability to work effectively as group member and to build cooperative effort within a team" as opposed to a technical skill, which primarily "is concerned with working with things (processes or physical objects)" (p. 91). Conceptual skills (3) are described as "the ability to see the enterprise as a whole" which involves "recognizing how the various functions of the organization depends on one another, and how changes in any one part affect all the others" and "extends to visualizing the relationship of the individual business to the industry, the community, and the political, social, and economic forces of the nation as 
a whole" (p. 93). Based on conceptual skills, a leader should "be able to act in a way which advances the over-all welfare of the total organization" (p. 93). According to Katz (1955) it is assumed that technical skills are not so important for the chief executives in large organisations where such executives have extensive staff assistance and highly competent, experienced technical operators available. However, in smaller organisations, technical expertise may not be pervasive and seasoned staff assistance less available. Thus, in this case, the chief executive has a much greater need for personal experience in the industry.

The leadership skills and competencies tradition of leadership theories after Katz divides leadership skills into technical, human and conceptual skills, where the first is especially important in first line leadership, but declining at higher levels in the leadership hierarchy according to Northouse. Conceptual skills are assumed to have the opposite development (Northouse, 2013). Opposed to leadership theories which focus on personality and the characteristics of the person that is a leader, the leadership skills venue focus is that there are many people that may have a potential for being a leader if they are able to learn from their experiences (Northouse, 2013). Thus, the focus of this leadership venue is «the capabilities (knowledge and skills) that make effective leadership possible» (Mumford, Zaccaro, Harding, Jacobs, \& Fleishman, 2000, p. 12).

Leadership skills, as described by Mumford and colleagues (Mumford, Marks, Connelly, Zaccaro, \& Reiter-Palmon, 2000; Mumford, Zaccaro, Connelly, \& Marks, 2000; Mumford, Zaccaro, Harding, et al., 2000) may be divided into (1) individual attributes, (2) competencies and (3) leadership outcomes, where the skills section includes problem-solving skills, ability for social decision making and knowledge of how to be effective (Northouse, 2013). Problem-solving skills is the ability to creatively "solve new and unusual, ill-defined organizational problems", social judgment skills is the "capacity to understand people and social systems", while knowledge is the "accumulation of information and the mental structures used to organize that information" (Northouse, 2013, pp. 48-51). In addition to the described tradition on leadership skills, there is also the idea of the "Leadership Pipeline" model. This model has been developed by Charan and colleagues and aims at understanding leadership requirements across hierarchical levels within an organization (see e.g., Dahl \& Molly-Søholm, 2012; Dai, Tang, \& De Meuse, 2011). While the Norwegian Police Directorate (NPD) has introduced co-workership as their main leadership initiative, such policies describe general leadership guidelines more than look into leadership requirements across hierarchical levels in the NPS.

In a study of police units, Yang and colleagues (Yang, Yen, \& Chiang, 2012) examined which factors influence job satisfaction among employees and the impact on project success. Project leaders attempt to increase job satisfaction among their employees can improve the employees' motivation and morale as well as the quality of project execution itself. The results showed 
that job satisfaction could mediate (and be an intervening variable that may be an indirect cause, see eg., Skog, 2004) the relationship between leadership skill and project success (Yang et al., 2012). The results further showed that complexity, workload, methodology and project length had a moderating effect on the relationship between job satisfaction and project planning success. According to the authors, leadership skills, such as intellectual, leader, emotional and social skills are necessary for achieving job satisfaction among their employees in the form of, for example, personal growth, relationships and perceived opportunities for advancement. However, despite an increased focus on leadership skills, Yang and colleagues state that "no previous studies have empirically analysed leadership competency and its impacts on police project performance" and that none of the previous studies they had undergone "attempted to deal with the benefits of leadership competency", despite that the lack of it often is one of the biggest obstacles to the exercise of police projects (Yang et al., 2012, p. 542).

Experience on the development of leadership skills from the Swedish Police Service (SPS) has shown that they have divided all leadership roles into three, namely (1) the business manager, where it is expected that the leader develops the business so that it achieves the expected goals, including follow-up and "take action" if necessary. As a manager, regardless of level, one should contribute to an open and tolerant culture in which diversity and equality is a matter of course; (2) the employer role, that leaders at all levels should take on, and take responsibility for employer policy and leading from the employers mandate, duties and rights and interacts with other leaders; and (3) leadership, to achieve tangible results with the help of employees. To motivate, support, develop employees, communicate, create dialogue with participation. The aim of the SPS leadership policy is that all leaders know the expectations to and from them.

Regarding leadership levels, the SPS have further described three leadership levels. The (1) direct leadership (frontline management) level includes executives who have no leaders between themselves and their employees. The (2) indirect leadership level (mid-level management) includes leaders that may find themselves in between strategic management and operational activities; leaders who lead through other leaders. The (3) strategic leadership level (top-management level) sets out framework and operational guidelines to be followed. These leaders work towards the outside world and have long term and visionary focus, and must be able to interpret and understand the demands of society to the police, as presented as conceptual skills earlier. Compared to the NPS, the SPS have made divisions in leadership levels and developed clear leadership skills and competencies at all levels, although actions to develop similar procedures are being undertaken. In the SPS, leadership education is attuned to the developed leadership levels in a systematic manner. According to an evaluation report, the programs are "characterised by high relevance and quality" and have "contributed to developing particular police leaders 
and to an increased unity in the organizational leadership and management. It may, to high extent, be regarded as a well-functioning program, based on its mandate and scope of action" (Rambøll, 2012, pp. 1-2, translated by the authors).

In the Danish Police Service (DPS), leadership levels have been divided into four, with (1) Professional leadership, (2) Staff leadership, (3) Administrative leadership, and (4) Strategic leadership. In addition, these four levels are guided by four leadership perspectives. One of these perspectives is direct leadership, which in this context is characterized by an authoritarian leadership style that may be used at all levels at the strategic, operational and tactical levels. This leadership perspective is applicable when there is a risk to their own or someone else's life, or when needed for coordination of efforts for example inter-sectorial efforts. In the DPS, leadership education is now attuned to the presented leadership levels and perspectives in a systematic manner. To our knowledge ${ }^{1}$ there have been none systematic investigations of students satisfaction regarding the present leader development programs during the last years, as well as none external evaluations as in the SPS. There have, however been introduced new demands for police leaders within the DPS, as of 1st of January 2015. Thus, as with co-workership, it may seem as leadership competence and skills in the police especially, until now, are more policy based interventions than empirically evolved ways of increasing leadership outcome in the police.

\section{Value-Based Leadership Policy into Practice}

The change in leadership policy may mean incremental or radical change in the actual leadership practice. If it is a radical change, institutional entrepreneurship, institutional leadership or creative leadership will be needed. Selznick (1957) draws a distinction between administrative management and institutional leadership. One aspect of institutional (creative) leadership is the institutional embodiment of purpose, and this is "a challenge to creativity because it involves transforming men and groups from neutral, technical units into participants who have a peculiar stamp, sensitivity and commitment. This is ultimately an educational process" (Selznick ,1957, pp. 158-159). It requires a strategy of change that looks to the attainment of new capabilities more nearly fulfilling the truly felt needs and aspiration of the institution. The executive becomes a statesman as he makes the transition from administrative management to institutional leadership (Selznick, 1957, p. 154), and is able to implement and integrate the mission, basic policy and organizational values in the social structure. Social structure refers to the patterned or regularized aspects of the relationships existing among actors in an organization (Scott, 1992) and can analytically be separated into two components: the normative structure (values, norms and role expectations)

1 Personal communication, Bo Jonasson, DPS, 2. 9. 2015. 
and the behavioral structure (actual behavior rather than prescriptions for behavior).

Normally a policy is developed by a small core of team members, but implementation will require deployment of significant amount of resources to overcome organizational inertia and resistance to secure the commitment of organizational members on whom implementation would depend (Raub, 2001). The policy should be communicated vertically in a convincing way between management levels (Figure 1) as the desired future practice to achieve understanding and acceptance among the managers on all levels and employees in the whole organization.

Figure 1: Conceptual leadership framework

\begin{tabular}{|c|c|c|c|c|}
\hline \multicolumn{5}{|c|}{ Norvegian Police Service's Mission and Vision } \\
\hline Values & \multicolumn{4}{|c|}{ Ethical values - Democratic values - Professional values - Personal values } \\
\hline Priorities & \multicolumn{2}{|c|}{$\begin{array}{l}\text { Performance, Competencies, } \\
\text { Development, Learning }\end{array}$} & Involvement & $\begin{array}{l}\text { Cooperation and } \\
\text { Coordination }\end{array}$ \\
\hline $\begin{array}{l}\text { Leadership } \\
\text { functions }\end{array}$ & STRATEGY & OPERATIONS & RELATIONS & $\begin{array}{l}\text { INFORMATION AND } \\
\text { COMMUNICATION }\end{array}$ \\
\hline $\begin{array}{l}\text { Executive Management } \\
\text { Level } 1\end{array}$ & \multicolumn{4}{|c|}{ EXECUTE AND STIMULATE TRANSFORMATIONAL LEADERSHIP } \\
\hline $\begin{array}{l}\text { Mid-level Management } \\
\text { Level } 1\end{array}$ & \multicolumn{4}{|c|}{ EXECUTE AND STIMULATE TEAM LEADERSHIP } \\
\hline $\begin{array}{l}\text { Frontline Management } \\
\text { Level } 1\end{array}$ & \multicolumn{4}{|c|}{ STIMULATE EMPLOYEESHIP (SELF LEADERSHIP) } \\
\hline Managerial skills & $\begin{array}{l}\text { Conceptual } \\
\text { Strategy }\end{array}$ & $\begin{array}{l}\text { Professional } \\
\text { policing skills }\end{array}$ & Behaviour skills & $\begin{array}{l}\text { Communicative } \\
\text { skills }\end{array}$ \\
\hline
\end{tabular}

A critical success-factor for implementing and integrating the new leadership policy will be necessary and adequate social support and this has to do with understanding the elements of the social structure assigned roles (division of labor), internal interest groups (sources of energy), social stratification (hierarchy), beliefs (culture), participation (affects communication) and dependency (line, staff) (Selznick, 1957).

These six elements of social structure, taken together, form a complex network of relations among persons and groups. The network acts as a filter through which policy is communicated; and it represents a system of accommodation among potentially conflicting parts. As a result, policy may be nullified 
in the filtering process, and any imbalance may lead to active measures for self-protection or aggrandizement by constituent units. To become the master of his/her organization, the leader must know how to deal with the social structure in all its dimensions, and "a self-renewing organization can be built only on the bedrock of people who are willing to take personal initiative and to cooperate with one another, who have self-confidence and a commitment to the company, and who are able to execute relative routine tasks with the same proficiency as they are willing to learn new skills and ways to take the company to the next stages of its ambition. In a classical article, Bartlett and Ghoshal (1995) claim that the most vital requirement for revitalizing businesses is to rejuvenate people.

\section{Conclusion}

Implementing and integrating a value-based leadership policy must be communicated, promoted, supported and advanced on all management levels. The executive (top) management level must execute and stimulate transformational leadership and see to that transformational leadership processes are anchored on the core values that are present in the organization and based on high ethical standards. The middle-management must execute and stimulate team leadership in interaction with the frontline management to facilitate interpretation and translate the more general values into functional values. The front-line management should then be able to stimulate the self-leadership and realize the ideas and values behind employeeship into daily policing practice. The new leadership policy is built into the social structure of an organization when official aims and methods are spontaneously protected and advanced (Selznick, 1957, p. 100), or when "exposed theories" (values) have become "theories in use". 
Jan Ole Vanebo, PhD, is professor of Management and Management Accounting at the North Troendelag University College and visiting professor at the Norwegian University Police College, in Norway. He is senior visiting fellow at EIPA (European Institute of Public Administration), Barcelona, and a member of the steering committee for EPSA 2015 (European Public Sector Award 2015). Professor Vanebo is co-editor of the book "Public Management in the Twenty-first Century - Trends, Ideas and Practices" (2013), University Press, Oslo, Norway.

Brita Bjørkelo, PhD, is a licensed Clinical Psychologist and works as an Associate Professor at the Department for further and continuing education, Norwegian Police University College, Oslo, Norway. Her PhD is on whistleblowing and she teaches different topics at Leadership and Management programs (Post Graduate Studies). She has papers on leadership, diversity, whistleblowing, bullying and sexual harassment in publications such as the International Handbook on Whistleblowing Research, Journal of Managerial Psychology, and Policing: A Journal of Policy and Practice. She is involved in research on Leader Competencies, Diversity, Ethics in Investigative Police Work and manages projects on Gender representation in top positions in Academe and on Ethics, Social Media and Teacher Education.

Terje Aaserud is an experienced Senior Lecturer at the Department for further and continuing education, Norwegian Police University College, Oslo, Norway. He teaches police officers in Leadership and Management (Post Graduate Studies). For the last years he has specially been doing action research on the topic Investigation Management and comparative research on police leadership development in the Scandinavian countries. 


\section{References}

Avolio, B. J., \& Gardner, W. L. (2005). Authentic leadership development: Getting to the root of positive forms of leadership. The Leadership Quartely, 16(3), 315-338. DOI: 10.1016/j.leaqua.2005.03.001

Barlett, C. A., \& Ghoshal, S. (1995). Rebuilding Behavioral Context: Turn Process Reengineering into People Rejuvenation. MIT Sloan Management Review, 37(1), 23-36.

Bass, B. M. (1991). From transactional to tranformational leadership: Learning to share the vision. Organizational Dynamics, 18(3), 19-31. DOI: $10.1016 / 0090-2616(90) 90061-S$

Busch, T., \& Murdock, A. (2014). Value-based Leadership in Public Professions. London: Palgrave Macmillan.

Cockcroft, T. (2014). Police Culture and Transformational Leadership: Outlining the Contours of a Troubled Relationship. Policing, 8(1), 5-13. DOI: 10.1093/police/pat040

Coleman, T. G. (2008). Managing strategic knowledge in policing: Do police leaders have sufficient knowledge about organisational performance to make informed strategic decisions? Police Practice and Research, 9(4), 307322. DOI: $10.1080 / 15614260802354593$

Dahl, K., \& Molly-Søholm, T. (2012). Leadership pipeline i den offentlige sektor. Denmark: Forfatterne og Dansk Psykologisk Forlag A/S.

Dai, G., Tang, K. Y., \& De Meuse, K. P. (2011). Leadership competencies across organizational levels: A test of the pipeline model. Journal of Management Development, 30(4), 366-380. DOI: 10.1108/02621711111126837

Ferlie, E., et al. (1996). The New Public Management in Action. Oxford: Oxford University Press. DOI: 10.1093/acprof:oso/9780198289029.001.0001

Fimreite, A. L., Langlo, P., Lægreid, P., \& Rykkja, L. H. (2013). After Oslo and Utøya: A Shift in the Balance between Security and Liberty in Norway? Studies in conflict and terrorism, 36(10), 839-856.

DOI: $10.1080 / 1057610 X .2013 .823754$

Fjærli, H. (2008). Lederstil i politi- og lensmannsetaten: En studie av lederstil i politi- og lensmannsetaten: I hvilken grad har denne betydning for effektiviteten, helsen og jobbtilfredsheten til de ansatte i politiet?, Masteroppgave (Master's thesis). Universitetet i Tromsø.

Gronn, P. (2002). Distributed leadership as a unit of analysis. The Leadership Quartely, 13(4), 423-451. DOI: 10.1016/S1048-9843(02)00120-0

Gundhus, H. I. (2013). Experience or Knowledge? Perspectives on New Knowledge Regimes and Control of Police Professionalism. Policing, 7(2), 178-194. DOI: $10.1093 /$ police/pas039

Hetland, H., \& Sandal, G. M. (2003). Transformational leadership in Norway: Outcomes and personality correlates. European Journal of Work and Organizational Psychology, 12(2), 147-170. DOI: 10.1080/13594320344000057

House, R. I. (1996). Path-goal theory of leadership: Lessons, legacy and a reformulated theory. The Leadership Quarterly, 7(3), 323-352. DOI: 10.1016/S1048-9843(96)90024-7

Katz, R. L. (1955). Skills of an effective administrator. Harvard Business Review, 1955(January-February), 33-42.

Kristensen, A. R., \& Pedersen, M. (2013). Strategisk selvledelse. København: Gyldendal Business. 
Mumford, M. D., Marks, M., Connelly, M. S., Zaccaro, S. J., \& Reiter-Palmon, R. (2000). Development of leadership skills: Experience and timing. The Leadership Quartely, 11(1), 87-114. DOI: 10.1016/S1048-9843(99)00044-2

Mumford, M. D., Zaccaro, S. J., Connelly, M. S., \& Marks, M. (2000). Leadership skills: Conclusions and future directions. The Leadership Quartely, 11(1), 155170. DOI: $10.1016 / \mathrm{S} 1048-9843(99) 00047-8$

Mumford, M. D., Zaccaro, S. J., Harding, F. D., Jacobs, T. O., \& Fleishman, E. A. (2000). Leadership skills for a changing wold: Solving complex social problems. The Leadership Quarterly, 11(1), 11-35. DOI: 10.1016/S10489843(99)00041-7

Northouse, P. G. (2013). Leadership: Theory and practice (6th ed.). Los Angeles: Sage.

Pearson-Goff, M., \& Herrington, V. (2014). Police leadership: A systematic review of the literature. Policing, 8(1), 14-26. DOI: 10.1093/police/pat027

Rambøll. (2012). Utvärdering av polisens chefsprogram. Rikspolisstyrelsen: Rambøll.

Raub, S. P. (2003). Towards a knowledge-based framework of competence development. In R. Sanchez (Ed.), Knowledge Management and Organizational Competence. Oxford: OUP. DOI: /10.1093/acprof:oso/9780199259281.003.0005

Sanchez, R., \& Heene, A. (2004). The New Strategic Management. New York: Johns Wiley \& Sons.

Selznick, P. (1957). Leadership in Administration : A Sociological Interpretation. New York: Harper \& Row.

Scott, R. (1992). Organizations: Rational, Natural, and Open Systems (3rd ed.). Englewood Cliffs, New Jersey: Prentice Hall.

Skog, O.-J. (2004). A forklare sosiale fenomener: En regresjonsbasert tilnærming (2. [revidert og utvidet] utg. ed.). Oslo: Gyldendal Akademisk.

Smith, D. E. (1965). Front-line organization of the state mental hospital. Administrative Science Quarterly, 10(3), 381-399. DOI: 10.2307/2391474

Tengblad, S. (2009). Medarbetarskap på 60 minuter. Behavioural Sciences: Högskolan i Skövde. Retrieved from https://www.his.se/PageFiles/2280/ MSKAP60min.pdf

Tengblad, S., \& Andersson, T. (2014). From industrial democracy to "coworkership": Development trends in work organization practices in Sweden. Paper presented at the International Labour Process Conference, London.

Tops, P. E. W. M., Bruijn, G. C. T., Spelier, R. F. J., Hogeboom, H., \& Arkel, D. (2012). The police as a learning frontline organisation. Tilburg School of Politics and Public Administration: Uitgeverij. Retrieved from https://pure.uvt. nl/portal/files/1502548/The police_as a learning frontline_organisation.pdf

Vanebo, J. O., \& Andersen J. A. (2014). Principles of Public Management in Scandinavian Countries: A theoretic Assessment. Mednarodna Revija Za Javno Upravo (International Public Administration Review), XII(1), 9-23.

DOI: 10.17573/ipar.2014.1.a01

van Ewijk, A. R. (2012). Diversity within police forces in Europe: A case for the comprehensive view. Policing, 6(1), 76-92. DOI: 10.1093/police/par048

Velten, J. (2008). Medarbeiderskap: Fra ord til handling. Oslo: Universitetsforl.

Yang, L.-R., Yen, H.-F., \& Chiang, Y.-F. (2012). A framework for assessing impacts of leadership competency on police project performance: Mediating role of job satisfaction and moderating role of project type. Policing: An international Journal of Police Strategies \& Management, 35(3), 528-550.

DOI: $\underline{10.1108 / 13639511211250785}$ 


\section{IZVLEČEK}

\subsection{Pregledni znanstveni članek}

\section{Razvoj vodenja policije: nameni in ključni dejavniki uspeha}

Norveška policija (NPS) je bila deležna številnih kritik po terorističnih napadih na otoku Utøya in v Oslu 22. julija 2011. Eno izmed ocenjevalnih poročil navaja tri pomanjkljivosti norveške policije, in sicer: kultura, odnosi in vodstvo. Upravo in vodstvo norveške policije je treba izboljšati in okrepiti, k čimer bo med drugim pripomogel tudi dokument o politiki vodstva v državnih službah, preoblikovan v manifest, imenovan Platforma organiziranja in vodenja zaposlenih v NPS-ju (Plattform for medarbeiderskap). Ta dokument politike se nanaša na to, kako bi bilo treba v splošnem upravljati javni sektor, sam dokument pa temelji na raziskavi o vodenju in je v skladu z glavno teorijo vodenja in upravljanja. V tem dokumentu je jasno predstavljena ideja o preoblikovanju klasičnih značilnosti principa vodenja. S tem v zvezi članek obravnava dve ključni vprašanji: kako se veščine vodenja policije, ki temeljijo na vrednoteh, dejansko uporabljajo in ocenjujejo ter kakšni so ključni dejavniki za prenos takih principov vodenja v izboljšano prakso. 